\title{
Accumulation of abdominal fat in relation to selected proinflammatory cytokines concentrations in non-obese Wrocław inhabitants
}

\author{
Gromadzenie trzewnej tkanki tłuszczowej a stężenie wybranych cytokin \\ prozapalnych u nieotyłych mieszkańców Wrocławia
}

\author{
Grażyna Bednarek-Tupikowska' ${ }^{1}$ Aleksandra Zdrojowy-Wełna ${ }^{1}$, Barbara Stachowska', \\ Justyna Kuliczkowska-Płaksej', Magdalena Matczak-Giemza' ${ }^{2}$,Eliza Kubicka' \\ Urszula Tworowska-Bardzińska' ${ }^{1}$, Andrzej Milewicz', Marek Bolanowski ${ }^{1}$ \\ ${ }^{1}$ Department of Endocrinology, Diabetology and Isotope Therapy, Wroclaw Medical University, Wroclaw, Poland \\ ${ }^{2}$ Lower Silesian Oncology Centre, Wroclaw, Poland
}

\begin{abstract}
Introduction: Metabolically obese normal weight (MONW) subjects, despite their normal BMI, present metabolic disturbances characteristic of abdominal obesity. One of the reasons might be subclinical inflammation caused by the fat tissue excess. The aim of this study was to assess the association between the accumulation of fat (especially abdominal) and the concentration of selected proinflammatory cytokines - interleukins (IL-6, IL-18) and C-reactive protein (CRP).

Methods and methods: The study population consisted of 342 subjects (218 women, 124 men; age $20-40$ years, BMI $<27 \mathrm{~kg} / \mathrm{m}^{2}$ ) recruited from a community centre in Wroclaw. The group was divided based on the homeostasis assessment insulin resistance index (HOMA) value: 90 MONW subjects with HOMA > 1.69 and 252 subjects as control group. Anthropometric parameters, serum IL-6, IL-18, CRP, glucose, insulin concentrations and insulin sensitivity/resistance indexes were evaluated.

Results: CRP levels were significantly higher (3.26 vs. 1.97, p = 0.03) in MONW women than in the control group. Serum IL-6, IL-18 levels in males and females did not differ in both groups. IL-6 showed a significant correlation with the abdominal to gynoidal fat tissue deposit ratio in women. There were correlations between the CRP and BMI, WHR, waist circumference, total fat, abdominal fat deposit, and abdominal to gynoidal fat deposit ratio in both sexes. In women, positive correlations between CRP and HOMA, FIRI and negative with QUICKI index were present.

Conclusions: Increased accumulation of abdominal adipose tissue in non-obese, young and healthy subjects is related to increased CRP levels. (Endokrynol Pol 2014; 65 (6): 449-455)
\end{abstract}

Key words: metabolically obese but normal weight subjects; subclinical inflammation; proinflammatory cytokines

\section{Streszczenie}

Wstęp: Osoby z zespołem metabolicznej otyłości z prawidłową masa ciała (MONW), mimo prawidłowego wskaźnika masy ciała (BMI), są narażone na powikłania typowe dla otyłości. Może to wynikać z subklinicznego stanu zapalnego, wynikającego z nadmiernego gromadzenia tkanki tłuszczowej brzusznej. Celem pracy była ocena związku pomiędzy nagromadzeniem tkanki tłuszczowej, szczególnie okolicy brzusznej, a stężeniem wybranych cytokin prozapalnych — interleukiny 6, 18 i białka C-reaktywnego (CRP), biorących udział w aterogenezie.

Materiał i metody: Badaniem objęto 342 osoby (218 kobiet, 124 mężczyzn w wieku 20-40 lat, z BMI < 27 kg/m²), mieszkańców Wrocławia. Grupę podzielono ze względu na wartość wskaźnika insulinooporności (HOMA): 90 osób — grupa MONW ( HOMA > 1.69), 252 osoby - grupa kontrolna. Oceniono parametry antropometryczne, stężenia IL-6, IL-18, CRP, glukozy, insuliny oraz wskaźniki insulinowrażliwości i insulinooporności.

Wyniki: Stężenie CRP było istotnie wyższe w grupie kobiet MONW niż kontrolnej (3,26 vs. 1,97, p = 0,03). Stężenia IL-6 i IL-18 nie różniły się pomiędzy grupami, zarówno u kobiet, jak i u mężczyzn. Dodatnią korelację zanotowano między stężeniem IL-6 a wskaźnikiem centralizacji tłuszczu u kobiet. Stwierdzono dodatnią korelację między stężeniem CRP a BMI, wskaźnikiem taliabiodra, obwodem talii u obu płci. U kobiet istniała także dodatnia korelacja między CRP a wskaźnikami HOMA i FIRI i ujemna ze wskaźnikiem QUICKI.

Wnioski: Zwiększone gromadzenie tłuszczu okolicy brzusznej u zdrowych, młodych osób, wiąże się z podwyższonym stężeniem CRP. (Endokrynol Pol 2014; 65 (6): 449-455)

Słowa kluczowe: otyłość z prawidłową masą ciała; subkliniczny stan zapalny; cytokiny prozapalne 


\section{Introduction}

Obesity contributes to the development of diabetes, atherosclerosis and related cardiovascular diseases (CVD) $[1,2]$. Studies attempting to explain the exact mechanism of CVD, atherosclerosis and its association with obesity are now of great importance. Obese people are prone to develop specific metabolic disorders, but also some non-obese people have a tendency to excess accumulation of abdominal fat with adverse metabolic consequences [3,4]. This concept was first brought up by Ruderman et al. and subjects belonging to this group are defined as metabolically obese normal weight (MONW) [3,5-8]. They are apparently healthy subjects, although a longitudinal study by Meigs et al. shows that the MONW phenotype is associated with a 3- to 4 -fold risk factor-adjusted increased relative risk for diabetes or CVD events [9]. There is no universal definition or uniform criteria of MONW syndrome or specific medical treatment. Insulin resistance/ /insulin sensitivity was the criterion in defining MONW group in most of the studies [5, 6, 9]. Conus et al. used HOMA over 1.69 as a cut-off value, based on their earlier studies using a euglycaemichyperinsulinaemic clamp [5].

Despite normal BMI, MONW subjects present increased adiposity, particularly in abdominal and visceral areas. This phenomenon may be associated with increased levels of proinflammatory cytokines. Adipose tissue is a very important source of increased secretion of proinflammatory cytokines [10-14]. Many publications on this subject concern obese people, whereas only a handful of studies have been conducted among MONW subjects. There have been few studies concerning the correlation between the amount of abdominal fat in MONW subjects and the level of inflammation markers, which are known to play a key role in the process of atherosclerotic plaque formation $[8,15,16]$. Recognition of such correlations in MONW subjects could help in the quick identification of affected people and allow early intervention.

Therefore, the aim of this study was to evaluate the association between abdominal adipose tissue deposit in non-obese males and females and blood level of selected proinflammatory cytokines - CRP, IL-6 and IL-18.

\section{Material and methods}

The study population consisted of 342 subjects -218 women and 124 men. Subjects were recruited from a community centre in Wroclaw and were included in the study if they met the following criteria: $20-40$ years of age, BMI $<27 \mathrm{~kg} / \mathrm{m}^{2}$. Exclusion criteria were as follows: presence of known diabetes, hypertension, or any other metabolic disorder, oral contraception, other drugs. Informed written consent was obtained from all participants. The study protocol was approved by the ethical committee. The study population was divided into subgroups based on the presence of the MONW syndrome, which was recognised on the basis of the insulin resistance HOMA index value. The cut-off point was 1.69 , according to the criteria outlined by Conus et al. [5]. Two subgroups were established: the MONW group, which comprised subjects with HOMA above 1.69 ( $\mathrm{n}=90,58$ women and $32 \mathrm{men})$, and the control group, which comprised subjects with HOMA up to $1.69(\mathrm{n}=252)$.

Body weight and height were measured in the morning. The BMI was calculated as body weight in kilograms divided by height in square metres $\left(\mathrm{kg} / \mathrm{m}^{2}\right)$. Waist circumference was measured at the umbilical level, hip circumference was measured at the widest part of the hip, and waist-to-hip ratio (WHR) was also calculated. Blood samples were drawn after an overnight fast (12 h) for plasma glucose, insulin. Fasting plasma glucose concentrations were measured using the glucose oxidase method (Dade Behring Marburg $\mathrm{GmbH}$, Germany, Xpand); serum insulin levels by a Micro Particle Enzyme Immunoassay (AxSym Insulin Kit, Abbott). Dual-energy X-ray absorptiometry was used to measure regional and whole body composition (Lunar DPX-plus, Lunar Corporation, Madison, WI, USA). Using the 'total body' option, the body fat content was calculated. The abdominal fat was calculated by assigning the percentage of fat in the area bounded from above by the upper rim coil L2 from the bottom of the lower edge of L4 in relation to the total body fat. The hip fat was calculated by assigning the percentage of fat in the area bounded from above by the trochanter major, from the bottom of the knee.

\section{Statistical analysis}

Variables were described using elements of descriptive statistics and included: minimum and maximum value, mean and standard deviation. The distribution of variables was examined using the Kolmogorov-Smirnov test. Comparisons between groups were performed using the Mann-Whitney-U test. In order to examine the correlation between the analysed indices, Spearman's rank correlation coefficient was calculated. Differences at the level below 0.05 were considered statistically significant. Results on the borderline of statistical significance $(0.05<\mathrm{p}<0.1)$ were also taken into account. Statistical calculations were performed using the computer program Statistica 6.0. 
Table I. Comparison of selected anthropomorphic and carbohydrate parameters in the MONW group and control subjects Tabela I. Porównanie wybranych parametrów antropometrycznych i wskaźników gospodarki węglowodanowej w grupie MONW $i$ kontrolnej

\begin{tabular}{llllll}
\hline & \multicolumn{2}{c}{ Non-obese normal (n $\mathbf{2 5 2})$} & U Mann-Whitney test & \multicolumn{2}{c}{ MONW (n = 90) } \\
\cline { 2 - 5 } & Means & SD & p-value & Means & SD \\
\hline Age (years) & 30.85 & 5.55 & 0.073831 & 29.67 & 5.66 \\
\hline Body weight [kg] & 63.75 & 11.67 & $<0.001$ & 69.95 & 11.40 \\
\hline Height [cm] & 170.35 & 9.45 & $<0.001$ & 173.67 & 8.77 \\
\hline BMI [kg/m & 21.82 & 2.47 & $<0.001$ & 23.06 & 2.35 \\
\hline Waist [cm] & 75.89 & 9.57 & $<0.001$ & 8.57 \\
\hline Hip [cm] & 98.38 & 5.67 & $<0.005$ & 5.96 \\
\hline WHR & 0.77 & 0.07 & $<0.001$ & 0.07 \\
\hline Total fat [g] & $15,729.29$ & $4,424.00$ & $<0.05$ & 100.47 & $6,199.77$ \\
\hline Total fat (\%) & 25.49 & 6.57 & 0.080 & 0.81 & 7.33 \\
\hline Abdominal deposit [g] & $1,139.91$ & 543.25 & $<0.001$ & $17,052.12$ & 631.38 \\
\hline Abdominal deposit (\%) & 21.59 & 6.78 & $<0.050$ & 24.47 & 7.58 \\
\hline Gynoidal deposit [g] & $4,819.74$ & $1,449.42$ & 0.226 & $1,402.58$ & $1,551.04$ \\
\hline Gynoidal deposit (\%) & 30.95 & 8.66 & $<0.01$ & 23.31 & 9.25 \\
\hline Abdominal/gynoidal deposit & 0.24 & 0.11 & $<0.01$ & $4,583.86$ & 0.14 \\
\hline Glucose [mg/dL] & 79.21 & 6.99 & $<0.001$ & 27.45 & 8.21 \\
\hline Insulin & 5.99 & 2.71 & $<0.01$ & 0.33 & 4.21 \\
\hline HOMA & 1.07 & 0.43 & $<0.01$ & 84.61 & 0.77 \\
\hline FIRI & 0.95 & 0.35 & $<0.001$ & 8.11 & 0.87 \\
\hline QUICKI & 0.40 & 0.05 & $<0.01$ & 2.33 & 0.03 \\
\hline
\end{tabular}

\section{Results}

\section{Antropometric parameters in study population}

The analysis performed independently of sex showed that all study parameters (body weight, BMI, waist and hip circumference, WHR) except for age were higher in the MONW group (Table I). Similar data was observed in groups of women and men separately (Tables II and III).

\section{Adipose tissue volume in study population}

The analysis of the study population showed that the total adipose tissue volume expressed in grams was significantly higher in MONW subjects than in normal subjects (Table I). MONW individuals were characterised by significantly higher accumulation of abdominal fat, both in grams and percentages, and lower accumulation of gynoid adipose tissue expressed as percentages, compared to normal controls. The value of abdominal/ /gynoidal deposit quotient was also significantly higher in MONW subjects. In the group of women, MONW subjects and controls revealed significant differences in the total adipose tissue volume and abdominal fat (Table II). Also, MONW subjects were characterised by significantly higher volume of adipose tissue and abdominal deposit. In the group of men, significantly higher adipose tissue mass in MONW subjects compared to normal subjects was observed (Table III). The difference in the abdominal and gynoidal deposit quotient in these groups was on the borderline of statistical significance and was higher in MONW subjects.

\section{Carbohydrate metabolism parameters in study population}

MONW subjects had significantly higher fasting glucose and insulin levels and significantly higher HOMA index. This is predictable, since the index was the criterion of division into the subgroups. Also, the other insulin resistance index (FIRI) was significantly higher, whereas the insulin sensitivity index (QUICKI) was significantly lower. These differences were observed both for the whole population and after division with regard to sex (Tables I-III).

\section{Serum inflammatory cytokines concentrations in study population}

The CRP concentration was higher in MONW women and men compared to control groups, but the difference was statistically significant in women only (Table IV). IL-18 and IL-6 levels did not reveal significant differences between both groups. 
Table II. Comparison of selected anthropomorphic and carbohydrate parameters in the MONW and control women

Tabela II. Porównanie wybranych parametrów antropometrycznych i wskaźników gospodarki węglowodanowej w grupie MONW i kontrolnej kobiet

\begin{tabular}{llllll}
\hline & \multicolumn{2}{c}{ Non-obese normal $(\mathbf{n}=\mathbf{1 6 0})$} & U Mann-Whitney test & \multicolumn{2}{c}{ MONW (n = 58) } \\
\cline { 2 - 5 } & Means & SD & p-value & Means & SD \\
\hline Age (years) & 29.35 & 6.55 & 0.06754 & 29.67 & 5.66 \\
\hline Body weight [kg] & 59.75 & 8.65 & $<0.001$ & 62.85 & 7.40 \\
\hline Height [cm] & 167.22 & 8.22 & $<0.05$ & 169.77 & 6.77 \\
\hline BMI [kg/m] & 21.55 & 1.99 & $<0.001$ & 23.00 & 1.35 \\
\hline Waist [cm] & 74.88 & 7.10 & $<0.001$ & 80.01 & 8.87 \\
\hline Hip [cm] & 97.13 & 4.57 & $<0.005$ & 99.48 & 5.01 \\
\hline WHR & 0.75 & 0.05 & $<0.001$ & 0.85 & 0.05 \\
\hline Total fat [g] & $16,215.18$ & $4,321.00$ & $<0.01$ & $17,022.66$ & $6,087.65$ \\
\hline Total fat (\%) & 27.11 & 6.22 & 0.16 & 27.18 & 6.01 \\
\hline Abdominal deposit [g] & $1,098.21$ & 499.34 & $<0.001$ & $1,322.44$ & 593.18 \\
\hline Abdominal deposit (\%) & 20.99 & 5.77 & $<0.001$ & 23.99 & 6.55 \\
\hline Gynoidal deposit [g] & $5,119.99$ & $1,529.44$ & 0.233 & $5,212.66$ & $1,531.11$ \\
\hline Gynoidal deposit (\%) & 34.98 & 8.00 & 0.061 & 28.33 & 8.15 \\
\hline Abdominal/gynoidal deposit & 0.22 & 0.15 & $<0.001$ & 0.35 & 0.12 \\
\hline Glucose [mg/dL] & 76.22 & 5.19 & $<0.001$ & 82.61 & 7.99 \\
\hline Insulin & 5.76 & 2.22 & $<0.01$ & 7.99 & 3.59 \\
\hline HOMA & 1.03 & 0.39 & $<0.01$ & 2.30 & 0.69 \\
\hline FIRI & 0.93 & 0.34 & $<0.001$ & 1.39 & 0.77 \\
\hline QUlCKI & 0.45 & 0.03 & $<0.01$ & 0.30 & 0.03 \\
\hline
\end{tabular}

Table III. Comparison of selected anthropomorphic and carbohydrate parameters in the MONW and control men

Tabela III. Porównanie wybranych parametrów antropometrycznych i wskaźników gospodarki węglowodanowej w grupie MONW i kontrolnej mężczyzn

\begin{tabular}{llllll}
\hline & \multicolumn{2}{c}{ Non-obese normal (n= 92) } & U Mann-Whitney test & \multicolumn{2}{c}{ MONW (n = 32) } \\
\cline { 2 - 5 } & Means & SD & p-value & Means & SD \\
\hline Body weight $[\mathrm{kg}]$ & 70.75 & 9.22 & $<0.010$ & 72.00 & 7.40 \\
\hline Height $[\mathrm{cm}]$ & 176.35 & 8.22 & 0.081 & 175.67 & 7.99 \\
\hline BMI $\left[\mathrm{kg} / \mathrm{m}^{2}\right]$ & 22.89 & 2.47 & $<0.001$ & 25.18 & 2.66 \\
\hline Waist $[\mathrm{cm}]$ & 86.99 & 9.57 & $<0.001$ & 82.00 & 9.57 \\
\hline Hip [cm] & 98.38 & 6.66 & $<0.010$ & 101.44 & 5.99 \\
\hline WHR & 0.86 & 0.06 & 0.071 & 0.89 & 0.06 \\
\hline Total fat [g] & $14,221.15$ & $4,111.00$ & $<0.05$ & $16,052.12$ & $5,223.27$ \\
\hline Total fat (\%) & 18.01 & 5.25 & 0.090 & 19.97 & 6.99 \\
\hline Abdominal deposit [g] & $1,234.51$ & 443.25 & 0.057 & $1,501.58$ & 521.15 \\
\hline Abdominal deposit (\%) & 17.99 & 5.28 & 0.061 & 20.11 & 6.11 \\
\hline Gynoidal deposit [g] & $3,205.56$ & $1,321.11$ & 0.146 & $3,583.86$ & $1,523.33$ \\
\hline Gynoidal deposit (\%) & 19.22 & 8.23 & 0.066 & 25.33 & 7.21 \\
\hline Abdominal/gynoidal deposit & 0.30 & 0.16 & 0.060 & 0.34 & 0.12 \\
\hline Glucose [mg/dL] & 87.33 & 7.21 & $<0.010$ & 91.66 & 9.07 \\
\hline Insulin & 6.01 & 2.99 & $<0.010$ & 9.01 & 3.21 \\
\hline HOMA & 1.10 & 0.29 & $<0.001$ & 2.48 & 0.61 \\
\hline FIRI & 0.99 & 0.31 & $<0.001$ & 2.28 & 0.81 \\
\hline OUICKI & 0.40 & 0.43 & $<0.010$ & 0.29 & 0.03 \\
\hline
\end{tabular}


Table IV. Serum concentrations of interleukin-18 (IL-18), interleukin-6 (IL-6), C-reactive protein (CRP) in MONW women and men and control groups

Tabela IV. Stężenia interleukiny 18 (IL-18), interleukiny 6(IL-6), białka C-reaktywnego (CRP) w grupach MONW i kontrolnych u kobiet $i$ mężczyzn

\begin{tabular}{|c|c|c|c|c|c|c|c|c|c|c|}
\hline & \multicolumn{5}{|c|}{ Women } & \multicolumn{5}{|c|}{ Men } \\
\hline & \multicolumn{2}{|c|}{ MONW (n = 35) } & \multicolumn{2}{|c|}{ Control $(n=183)$} & $\begin{array}{l}\text { U Mann-Whitney } \\
\text { test }\end{array}$ & \multicolumn{2}{|c|}{$\begin{array}{l}\text { MONW } \\
(n=55)\end{array}$} & \multicolumn{2}{|c|}{ Control $(n=69)$} & \multirow{2}{*}{$\begin{array}{l}\begin{array}{l}\text { U Mann-Whitney } \\
\text { test }\end{array} \\
\text { p-value } \\
\end{array}$} \\
\hline & Means & SD & Means & SD & p-value & Means & SD & Means & SD & \\
\hline IL-6 & 16.92 & 6.33 & 17.04 & 5.78 & 0.94 & 15.99 & 4.89 & 15.18 & 4.71 & 0.52 \\
\hline IL-18 & 240.48 & 65.05 & 248.01 & 84.29 & 0.72 & 276.52 & 75.44 & 291.83 & 98.99 & 0.51 \\
\hline CRP & 3.26 & 3.67 & 1.97 & 2.38 & 0.03 & 2.43 & 2.02 & 2.14 & 2.12 & 0.11 \\
\hline
\end{tabular}

Table V. The correlations between serum concentrations of IL-6, IL-18, CRP and anthropometric and serum glucose, insulin concentrations and insulin resistance and insulin sensitivity indices in women

Tabela V. Korelacje pomiędzy stężeniami IL-6, IL-18, CRP i parametrami antropometrycznymi, stężeniem glukozy, insuliny, insulinoopornościq oraz insulinowrażliwościq u kobiet

\begin{tabular}{lccccccccccc}
\hline & $\begin{array}{c}\text { Body weight } \\
{[\mathbf{k g}]}\end{array}$ & $\begin{array}{c}\text { BMI } \\
{\left[\mathbf{k g} / \mathbf{m}^{2}\right]}\end{array}$ & $\begin{array}{c}\text { Waist } \\
{[\mathbf{c m}]}\end{array}$ & $\begin{array}{c}\text { Hip } \\
{[\mathbf{c m}]}\end{array}$ & WHR & $\begin{array}{c}\text { Fasting } \\
\text { glucose }[\mathbf{m g}]\end{array}$ & $\begin{array}{c}\text { Insulin } \\
{[\mu / \mathrm{lU} / \mathbf{m L}]}\end{array}$ & HOMA & QUICKI & FIRI \\
\hline IL-6 & NS & NS & NS & NS & NS & 0.27 & NS & 0.39 & NS & 0.39 \\
\hline IL-18 & 0.15 & NS & 0.17 & NS & 0.15 & NS & NS & NS & NS & NS \\
\hline CRP & 0.25 & 0.27 & 0.36 & 0.27 & 0.17 & NS & 0.23 & 0.23 & -0.19 & 0.23 \\
\hline
\end{tabular}

Correlations between inflammatory cytokines and:

\section{- anthropometric parameters}

In the group of women, statistically significant positive correlations were observed between CRP level and body mass, BMI, waist and hip circumference and WHR. IL-18 level was positively correlated with body mass, waist, WHR (Table V). CRP level in men, similarly to women, was positively correlated to BMI, waist circumference and WHR. IL-18 in men was significantly correlated only with hip circumference (Table VI). IL-6 level did not reveal statistically significant correlations with any of the analysed anthropometric parameters (Tables V and VI).

\section{- carbohydrate metabolism parameters}

The CRP level in the group of women revealed statistically significant positive correlations between insulin levels, HOMA and FIRI indices, and a negative correlation with the QUICKI index. No significant correlations between IL18 levels and all study parameters of carbohydrate metabolism were observed. IL-6 levels were positively correlated with glucose level, HOMA and FIRI index in women only (Table V). In the group of men, no correlation was observed between the level of all studied inflammation markers and carbohydrate metabolism parameters (Table VI).

\section{- adipose tissue content}

The total adipose tissue volume, as well as the volume of abdominal and gynoidal deposit and the abdominal/ /gynoidal deposit ratio in the group of women, showed significant correlations with CRP level. IL-6 was positively correlated only with the abdominal/gynoidal deposit ratio (Table VII). In the group of men, the total fat volume and fat deposited in abdominal region, as well as the centralisation index, showed significant positive correlations only with CRP level (Table VIII).

\section{Discussion}

In a review of MONW individuals, Ruderman et al. noted that MONW subjects have increased adipose tissue mass compared to normoinsulinaemic individuals of similar height and weight [4]. Elevated abdominal visceral fat can be a risk factor for the development of metabolic abnormalities also in people who are regarded as nonobese, because it contributes to insulin resistance [7]. In a cross-sectional survey consisting of more than 7,000 subjects in U.S., the prevalence of the metabolic syndrome (due to ATPIII criteria) increased from $0.9-3.0 \%$ at BMI $18.5-20.9 \mathrm{~kg} / \mathrm{m}^{2}$ to $9.6-22.5 \%$ at BMI $25.0-26.9 \mathrm{~kg} / \mathrm{m}^{2}$ [17]. In a previous study conducted in Poland, using a definition based on HOMA value over 1.69, we found that MONW syndrome frequency was $21.76 \%$ in women and $31.42 \%$ in men with BMI below 25 [18]. In our present study, based on a Wrocław population, MONW subjects were characterised by BMI up to 27 and insulin resistance measured by the HOMA value was also the basic criterion. 
Table VI. The correlations between IL-6, IL-18, CRP levels and anthropometric parameters, glucose, insulin levels, insulin resistance and insulin sensitivity in men

Tabela VI. Korelacje pomiędzy stężeniami IL-6, IL-18, CRP i parametrami antropometrycznymi, stężeniem glukozy, insuliny, insulinoopornościq̨ oraz insulinowrażliwościq u mężczyzn

\begin{tabular}{lcccccccccc}
\hline $\begin{array}{c}\text { Body weight } \\
{[\mathbf{k g}]}\end{array}$ & $\begin{array}{c}\text { BMI } \\
{\left[\mathbf{k g} / \mathbf{m}^{2}\right]}\end{array}$ & $\begin{array}{c}\text { Waist } \\
{[\mathbf{c m}]}\end{array}$ & $\begin{array}{c}\text { Hip } \\
{[\mathbf{c m}]}\end{array}$ & WHR & $\begin{array}{c}\text { Fasting } \\
\text { glucose }[\mathbf{m g}]\end{array}$ & $\begin{array}{c}\text { Insulin } \\
{[\boldsymbol{\mu l U} / \mathbf{m L}]}\end{array}$ & HOMA & QUICKI & FIRI \\
\hline IL-6 & NS & NS & NS & NS & NS & NS & NS & NS & NS & NS \\
\hline IL-18 & NS & NS & NS & 0.20 & NS & NS & NS & NS & NS & NS \\
\hline CRP & NS & 0.17 & 0.21 & NS & 0.18 & NS & NS & NS & NS & NS \\
\hline
\end{tabular}

Table VII. The correlations between adipose tissue and its abdominal and gynoidal deposit and cytokine concentrations in the group of women

Tabela VII. Korelacje pomiędzy ilościq tkanki ttuszczowej trzewnej i gynoidalnej ze stężeniem cytokin w grupie kobiet

\begin{tabular}{llllllll}
\hline Total fat [g] & Total fat (\%) & $\begin{array}{l}\text { Abdominal } \\
\text { deposit [g] }\end{array}$ & $\begin{array}{l}\text { Abdominal } \\
\text { deposit (\%) }\end{array}$ & $\begin{array}{l}\text { Gynoidal deposit } \\
{[\mathrm{g}]}\end{array}$ & $\begin{array}{l}\text { Gynoidal deposit } \\
\text { (\%) }\end{array}$ & $\begin{array}{l}\text { Abdominal/ } \\
\text { gynoidal deposit }\end{array}$ \\
\hline IL-6 & NS & NS & NS & NS & NS & NS & 0.16 \\
\hline IL-18 & NS & NS & NS & NS & NS & NS & NS \\
\hline CRP & 0.29 & 0.26 & 0.29 & 0.27 & 0.22 & 0.19 & 0.19 \\
\hline
\end{tabular}

Table VIII. The correlations between adipose tissue and its abdominal and gynoidal deposit and cytokine concentrations in the group of men

Tabela VIII. Korelacje pomiędzy ilością tkanki tłuszczowej trzewnej i gynoidalnej ze stężeniem cytokin w grupie mężczyzn

\begin{tabular}{llllllll}
\hline & Total fat [g] & Total fat (\%) & $\begin{array}{l}\text { Abdominal } \\
\text { deposit }[\mathrm{g}]\end{array}$ & $\begin{array}{l}\text { Abdominal } \\
\text { deposit }(\%)\end{array}$ & \multicolumn{2}{c}{$\begin{array}{l}\text { Gynoidal deposit Gynoidal deposit Abdominal/ } \\
{[\mathrm{g}]}\end{array}$} & $\begin{array}{l}\text { (\%) } \\
\text { gynoidal deposit }\end{array}$ \\
\hline IL-6 & -0.18 & -0.18 & -0.18 & -0.18 & -0.14 & -0.16 & -0.12 \\
\hline IL-18 & 0.18 & 0.09 & 0.18 & 0.15 & 0.02 & -0.03 & 0,15 \\
\hline CRP & 0.36 & 0.35 & 0.44 & 0.34 & 0.08 & 0.18 & 0.35 \\
\hline
\end{tabular}

MONW individuals in our study presented a higher accumulation of abdominal fat, both in grams and percentages, and a lower accumulation of gynoid adipose tissue expressed as percentages, compared to normal controls. This accumulation of central fat in normal weight subjects promotes the production of proinflammatory cytokines. Hyun et al. have noted that MONW women with BMI $<25 \mathrm{~kg} / \mathrm{m}^{2}$ but a high volume of visceral adipose tissue (VFA $>100 \mathrm{~cm}^{3}$ ) showed higher concentrations of tumour necrosis factor $\alpha$ (TNF- $\alpha$ ), IL-6, leptin and CRP but a lower plasma concentration of adiponectin compared to normal controls [8].

Increased adipose tissue volume, especially that located in the abdominal region, is known to be related to increased CRP in blood [19]. In their study, Bo et al. observed a significant correlation between the total content of adipose tissue and the CRP level in healthy subjects [20]. Our results agree with those findings we have found that there are significant positive correlations between the total adipose tissue volume and the CRP level in both men and women.
The volume of abdominal fat deposits and abdominal/gynoidal deposits ratio in both groups were also positively correlated with the level of this cytokine. As a natural consequence, we found that CRP was higher in MONW women than in controls, and in men we observed the same trend. However, it did not reach statistical significance. The results show that CRP level is correlated with insulin resistance, especially in the group of non-obese women. This has important clinical implications because in large prospective studies among postmenopausal women, hs-CRP was a strong univariate predictor of the risk of cardiovascular events: the relative risk of events for women in the highest quartile compared to the lowest quartile for this marker was 4.4 [14].

So, elevated serum CRP in apparently healthy subjects may be a predictor for accelerated development of atherosclerosis and cardiovascular complications, because it is associated with increased central fat accumulation and insulin resistance.

In our study, IL-18 presented no correlation with the adipose tissue mass and distribution but only with waist 
circumference and WHR index in women. The data presented in available publications remains unclear. The Dallas Heart Study revealed the correlation of IL-18 with BMI, total fat volume, visceral fat assessed with waist circumference and WHR index, as well as lean body mass [21]. There are also studies showing no differences in IL-18 levels between obese and normal subjects. In those studies, there was no correlation between the IL-18 level and BMI, adipose tissue content and distribution [22]. The authors of these studies claim that the lack of correlation between IL-18 level and body mass, especially fat content, undermines the importance of adipose tissue as the main source of this cytokine in serum. Other studies contradict these results, e.g. Skurk et al. evaluated expression of mRNA for IL-18 and secretion of this cytokine by adipocytes and preadipocytes from adipose tissue collected during surgical procedures. They recorded higher IL-18 levels in obese subjects [23]. The role of IL-18 in the development of metabolic abnormalities seems to be significant and requires further research; its elevated concentration has been suggested to be a risk factor for metabolic syndrome independently of obesity [11]. Moreover, IL-18 is highly expressed in atherosclerotic plaques, probably promoting its instability [24]. That could increase cardiovascular mortality in MONW subjects observed in recent studies [25].

The results of the present study have shown a correlation between IL-6 level and abdominal/gynoidal deposit ratio in women. One third of IL-6 circulating in vessels comes from adipose tissue, and this amount is even greater in obese subjects. Increased IL-6 levels are related to insulin resistance and constitute a risk factor for the development of type 2 diabetes mellitus and cardiovascular diseases [26]. Some studies have shown elevated IL-6 concentrations in individuals with excessive fat mass $[8,15]$, and the positive correlations with the abdominal/gynoidal deposit ratio in women in our study might also suggest this association.

Increased IL-6 levels may be considered an early and sensitive marker of inflammation. Its determination, however, is rarely useful due to high circadian fluctuations of serum level of this cytokine, which means that it is less important as a marker of inflammation than CRP [27]. The highest IL-6 release from the subcutaneous adipose tissue was recorded in evening hours. Perhaps the above-mentioned circadian changes in IL-6 level underlie the fact that the present study has not revealed a clear correlation between adipose tissue volume and IL-6 level or differences of IL-6 concentration between MONW and control group.

\section{Conclusions}

The accumulation of abdominal fat in young healthy and non-obese subjects is associated with increased synthesis of CRP. An assessment of abnormal serum CRP level may be helpful in the early identification of subjects with an increased risk of atherosclerosis. Then it would be possible to undertake preventive actions.

\section{References}

1. World Health Organization. Obesity: preventing and managing the global epidemic. Geneva (Switzerland): World Health Organization; 1977.

2. Definition, diagnosis and classification of diabetes mellitus and its complications: Report of a WHO Consultation. Geneva, Switzerland: Department of Noncommunicable Disease Surveillance, World Health Organization; 1999. http://whqlibdoc.who.int/hq/1999/WHO_NCD_NCS_99.2.pdf

3. Ruderman NB, Schneider SH., Berchtold P. The "metabolically obese normal weight" individual. Am J Clin Nutr 1981; 34: 1617-1621.

4. Ruderman NB, Chisholm D, Pi-Sunyer X et al. The metabolically obese, normal weight individual — revisited. Diabetes 1998; 47: 699-713.

5. Conus F, Allison DB, Rabasa-Lhoret R et al. Metabolic and behavioral characteristics of metabolically obese but normal-weight women. J Clin Endocrinol Metab 2004; 89: 5013-5020.

6. Dvorak RV, De Nino WF, Ades PA et al. Phenotypic characteristics associated with insulin resistance in metabolically obese but normal- weight young women. Diabetes 1999; 48: 2210 -2214.

7. Katsuki A, Sumida Y, Urakawa $\mathrm{H}$ et al. Increased visceral fat and serum levels of triglyceride are associated with insulin resistance in Japanese metabolically obese, normal-weight subjects with normal glucose tolerance. Diabetes Care 2003; 26: 2341-2344.

8. Hyun YJ, Koh SJ, Chae JS et al. Atherogenecity of LDL and unfavorable adipokine in metabolically obese, normal-weight woman. Obesity 2008 16: 764-789.

9. Meigs 2006

10. Dohi $\mathrm{Y}$, Takase $\mathrm{H}$, Sato $\mathrm{K}$ et al. Association among C-reactve protein oxidative stress, and traditional risk factors in healthy Japanese subjects. Int J Cardiol 2007; 115: 63-66.

11. Hung J, McQuillan BM, Chapman CM et al. Elevated interleukin-18 levels are associated with the metabolic syndrome independent of obesity and insulin resistance. Arterioscler Thromb Vasc Biol 2005; 25: 1268-1273.

12. Herder C, Baumert J, Kolb H et al. Circulating levels of interleukin-18 independent of body fat and fat-free mass: results from the MONICA KORA study. Diabetes Care 2006; 29: 174-175.

13. Skowrońska B,Fichna M, Fichna P.Rola tkanki tluszczowej w układzie dokrewnym. Endokrynologia, Otyłości Zaburzenia Przemiany Materii 2005; 3: 21-29.

14. Ridker PM, Hennekens $\mathrm{CH}$, Buring JE et al. C-reactive protein and other markers of inflammation in the prediction of cardiovascular disease in women. N Engl J Med 2000; 342: 836-843.

15. De Lorenzo A, Del Gobbo V, Premrov MG et al. Normal-weight obese syndrome: early inflammation. Am J Clin Nutr 2007; 85: 40-45.

16. Di Renzo L, Bigioni M, Del Gobbo V et al. Interleukin-1 (IL-1) receptor antagonist gene polymorphism in normal weight obese syndrome: relationship to body composition and IL-1 alpha and beta plasma levels. Pharmacol Res 2007; 55: 131-138.

17. St-Onge MP, Janssen I, Heymsfield SB. metabolic syndrome in normalweight Americans: new definition of the metabolically obese, normaweight individual. Diabetes Care 2004; 27: 2222-2228.

18. Bednarek-Tupikowska G, Stachowska B, Miazgowski T et al. Evaluation of the prevalence of metabolic obesity and normal weight among the Polish population. Endokrynol Pol 2012; 63: 447-455.

19. Visser M, Bouter LM, McQuillan GM et al. Elevated C-reactive protein levels in overweight and obese adults. JAMA 1999; 282: 2131-2135.

20. Bo M, Raspo S, Morra F et al. Body fat and C-reactive protein levels in healthy non-obese men. Nutr Metab Cardiovasc Dis 2004; 14: 66-72.

21. Zirlik A, Abdullah SM, Gerdes N et al. Interleukin-18, the metabolic syndrome, and subclinical atherosclerosis: results from the Dallas Heart Study. Arterioscler Thromb Vasc Biol 2007; 27: 2043-2049.

22. Vilarrasa N, Vendrell J, Maravall J et al. IL-18: relationship with anthropometry, body composition parameters, leptin and arterial hypertension. Horm Metab Res 2006; 38: 507-512

23. Skurk T, Kolb H, Müller-Scholze S et al. The proatherogenic cytokine interleukin-18 is secreted by human adipocytes. Eur J Endocrinol 2005; 152: 863-868.

24. Mallat Z, Corbaz A, Scoazec A et al. Expression of IL-18 in human atherosclerotic plaques and relation to plaque instability. Circulation 2001; 104: 1598-1603.

25. Choi KM, Cho HJ, Choi HY et al. Higher mortality in metabolically obese normal weight people than in metabolically healthy obese subjects in elderly Koreans. Clinical Endocrinology 2013; 79: 364-370.

26. Kershaw EE, Flier JS. Adipose Tissue as an Endocrine Organ. J Clin Endocrinol Metab 2004; 89: 2548-2556.

27. Gerenli M, Tugrul A, Demir M et al. The relationship between proinflammatory cytokine levels and fibrinolytic system in simple obese patients. http://www.tutfd.org/text.php3?id = 150 